\title{
In vitro Adherence of Sheep Red Cells to Macrophages of Normal Rats
}

In experiments with Charles River rats inoculated with sheep red cells, we were surprised to see that peritoneal macrophages from normal control rats, provoked in vitro adherence of these erythrocytes, forming 'rosettes' 1 like those of immunized rats. Consequently, we investigated: (a) if the cyto-adherence phenomenon (rosettes formation) occurs in all normal rats and if it is related to age, strain or breeding house; (b) if the macrophage activity is paralled by circulating antibodies; (c) how this cytoadherence is influenced by immunization with sheep red cells.

For this purpose we examined 2 strains of albino rats at the age of 2 weeks to 7 months from 3 different breeding houses: Mephalsim (Charles River), Löwenstein (Wistar C.D.), and Tel-Aviv University (Wistar C.D. and Charles River). A first group of 90 normal rats (from the different breeding houses) was examined for the ability of macrophages to attach sheep red cells in vitro. Splenic cells were investigated by the hemolysin plaque formation method ${ }^{3}$, to detect antibody-forming cells. Peritoneal fluids (medium 199 with $1 \%$ heparin was injected j.p. for macrophage harvest ${ }^{4}$ ) and sera were examined for complete or incomplete antibodies for sheep red cells ${ }^{6,6}$, cytophilic antibodies ${ }^{1}$ and cold agglutinins. A second group of 20 normal rats was examined for evolution of macrophage ability to bind sheep red cells, by repeated peritoneal punctures (at 3-4 week intervals), and for circulating antibodies.

The rosette-forming capacity of 'normal' rat cells seems related to the breeding place, not to age or strain. Rats from Löwenstein and Tel-Aviv University breedings, generally $(86 \%)$ gave strong positive results in the cytoadherence test (about $400-1000$ red cells/100 macrophages), whereas macrophages from rats of Mephalsim breeding were negative. Animals from 'positive' breeding places gave positive results already at $2-3$ weeks of age, the reaction being generally weaker in very young ones, than in adults. Young or adult rats from Mephalsim breeding, whose macrophages showed no rosette formation, started to be 'positive' 2-3 months after being brought to Tel-Aviv University breeding. (Rats of the same age or older, which stayed in their original breeding place, were still negative.)

The cyto-adherence was influenced by peritoneal fluid. When sheep red cells were added to unwashed macrophages from positive rats, adherence was followed by lysis of red cells, probably because of complement being present in the fluid ${ }^{4,7}$. If red cells were added to washed macrophages, cyto-adherence was stronger. If withdrawn ascitic fluid was inactivated $\left(56^{\circ} \mathrm{C}, 30 \mathrm{~min}\right)$ and then added to washed macrophages, no lysis occurred, but cyto-adherence was enhanced, probably by disappearance of an inhibitor present in fresh fluid. Addition of fresh or inactivated ascitic fluid from positive rats to macrophages from negative ones, conferred on them the ability to bind sheep red cells; sera of the same positive rats, had, however, no influence on non-rosette-forming macrophages. This suggests that cytophilic antibody was present only in the peritoneal fluid. Complete or incomplete antibodies to sheep red cells, cytophilic antibodies, or cold agglutinins were absent in sera from positive rats. No antibodyforming cells as measured by the method of JERNE et al. ${ }^{3}$ could be detected in spleens of positive normal rats. Whatever the activity of peritoneal cells, alveolar macrophages never bound sheep red cells.

When the rats were inoculated with sheep red cells (with or without complete Freund's adjuvant) their peritoneal as well as alveolar macrophages showed adherence of sheep red cells 5 days after inoculation, with a peak at 15-20 days, independent of prior reactivity, strain, age or breeding house. A week after inoculation, 'positive' rats reacted stronger than 'negative' ones; no difference was noted later. Plaque-forming cells ${ }^{3}$ were detectable and hemagglutinins, hemolysins and cytophilic antibodies were present in all inoculated animals.

The fact that 'negative' rats became 'positive' when moved to another breeding place, could be explained by the presence in 'positive' breeding places of an antigen which has antigenic determinants in common with sheep red cells. Why this should affect the peritoneal and not the alveolar macrophages is not clear at the present time. The presence of an inhibitor of the rosette-formation in fresh ascitic fluid is in agreement with similar findings about fresh sera ${ }^{8}$. The fact that peritoneal macrophages of normal rats give cyto-adherence with sheep red cells, in the absence of serum antibodies, is quite opposite to what happens in normal guinea-pigs in which an incomplete serum antibody to erythrocytes was detectable as described by BOYDEN ${ }^{5,6}$. Significant adherence in vitro of sheep red cells around peritoneal macrophages of normal guinea-pigs has never been noted $1,2,4,7,8$. We suppose that the heat stable factor present in the ascitic fluid of positive rats, is a cytophilic antibody attached to tissues in the abdominal cavity. Experiments are in progress in our laboratory to establish the characteristics of this antibody ${ }^{9}$.

Résumé. Les macrophages péritonéaux de certains rats normaux provoquent in vitro l'adhérence des hématies de mouton, proprieté qui dépend de l'élevage et non de la race ou de l'âge. Un anticorps cytophile (absent chez les rats à macrophages inactifs pour ces hématies) est seulement présent dans les liquides de lavage péritonéaux, tandis que dans les sérums les anticorps (agglutinines complètes ou incomplètes, hémolysines, anticorps cytophiles) sont absents.

Jeanna Schwartz and Ora Degani with technical assistance of I. HUGY

Department of Microbiology, Tel-Aviv University, Tel-Aviv (Israel), 16 May 1967.

1 S. V. BOyden, Immunology 7, 474 (1964).

* G. BiozzI, C. Stiffel, D. Mouton, M. Liacopoulos-Briot, C. Decreusefond and Y. Bouttillier, Annls Inst. Pasteur, Paris 3, 1 (1966).

9 N. K. Jerne, A. Nordin and C. Henry, in Cell-bound Antibodies (Eds B. Amos and H. Koprowski; Wistar, Inst. Press, Philadelphia 1963), p. 109.

4 J. Schwartz, Experientia 23,496 (1967).

$5 \mathrm{~S}$. V. Boyden, in Molecular and Cellular Basis of Antibody Formation (Ed. STERZL and co-workers; Academic Press, N.Y., London 1965), p. 329.

6 S. V. BoYden in Advances in Immunology (Academic Press N.Y., London 1966), p. $5,1$.

7 A. Berken and B. Benacerraf, J. exp. Med. 1, 119 (1966).

8 W. E. Jonas, D. S. Gurner, D. S. Nelson and R. R. A. Coombs, Int. Archs Allergy appl. Immun. 28, 86 (1965).

- Acknowledgment. The authors are indebted to Prof. A. KLopstock, Head of the Department of Microbiology, Tel-Aviv University, for his helpful interest throughout this investigation. Thanks are due to I. HugY for excellent technical assistance. 